African Crop Science Journal by African Crop Science Society is licensed under a Creative Commons Attribution 3.0 Uganda License. Based on a work at www.ajol.info/ and www.bioline.org.br/cs DOI: https://dx.doi.org/10.4314/acsj.v27i2.12

\title{
GENOTYPE BY ENVIRONMENT INTERACTION AND GRAIN YIELD STABILITY OF ETHIOPIAN BLACK SEEDED FINGER MILLET GENOTYPES
}

\author{
D. KEBEDE, L. DAGNACHEW ${ }^{1}$, D. MEGERSA, B. CHEMEDA, M. GIRMA ${ }^{1}$, G. GELETA \\ and B. GUDETA
}

\author{
Bako Agricultural Research Center, P. O, Box 03, Bako, West Shoa, Ethiopia \\ ${ }^{1}$ Oromia Agricultural Research Institute, Addis Ababa, Ethiopia \\ Corresponding author: kebelem@gmail.com
}

(Received 19 June 2018; accepted 13 May 2019)

\begin{abstract}
Finger millet (Eleusine coracana (L.) Gaertn) is an important cereal widely produced in Ethiopia across diverse agro-ecologies. It is valued by local farmers for its ability to grow in adverse agro-climatic conditions, where other cereals fail. The yield potential of this crop is in the range of 4-5 tonnes/ha, but the current national average grain yield is far below the potential (2.1 tonnes). Lack of improve varieties which are stable, high yielder and stress tolerant is a major limiting factor to production of this crop in Ethiopia. A field experiment was conducted using twelve black seeded finger millet (Eleusine coracana subsp. coracana) genotypes, including local and standard checks (Degu) at two locations (Bako and Gute) in Ethiopia for three years (2014 - 2016). The objective of this study was to identify stable and high yielding genotypes for grain yield and other agronomic traits among the black seeded finger millet genotypes of Ethiopia. The additive main effect and multiplicative interaction (AMMI) model analysis of variance revealed highly significant $(\mathrm{P}<0.01)$ differences between environments, genotype, and Interaction Principal Component Analysis (IPCA-I), but significant variations $(\mathrm{P}<0.05)$ for $\mathrm{G} x \mathrm{E}$ interactions. This indicates that the genotypes performed differently over environments and that the test environments are highly variable. Only the first IPCA-I showed high significance $(\mathrm{P}<0.01)$ and contributed $48.39 \%$ of the total genotype by environment interaction ( $\mathrm{Gx}$ E). Genotypes BKFM0020, BKFM0006 and BKFM0010, which had high grain yield, but with IPCA value close to zero, indicated the wide adaptability/stability. Similarly, analysis using Eberhart and Russell model revealed that these genotypes were within the relatively acceptable range of regression coefficients (bi), approaching to one $(0.742,0.8176$ and 1.0578$)$, and deviation from regression closer to zero $\left(\mathrm{s}^{2} \mathrm{di}\right)(0.0385,-0.0661$ and -0.0248), respectively. This implied that pipeline genotypes were stable, widely adaptable and high yielders than the other genotypes. Genotype and genotype by environment (GGE bi-plot) analysis also revealed that these candidate genotypes were stable and high yielder. Besides, these genotypes showed resistance to blast disease, which is a threat to finger millet production in the study areas. Therefore, these genotypes were selected as potential candidates for possible release in western Oromia and similar agro-ecologies of the country.
\end{abstract}

Key Words: AMMI, blast, Eleusine coracana 
Le petit mil (Eleusine coracana (L.) Gaertn) est une céréale importante largement produite en Éthiopie dans les différents zones agro-écologiques. Il est apprécié par les agriculteurs locaux pour sa capacité de grandir dans des conditions agro-climatiques défavorables, où les autres céréales échouent. Le potentiel du rendement en grain de cette culture de mil se situe entre 4 à $5 \mathrm{t} \mathrm{ha}^{-1}$, mais le rendement moyen national actuel est très inférieur au potentiel ( 2,1 tonnes). Le manque de variétés améliorées, stables, à rendement en grain élevé et tolérantes au stress est un $\mathrm{t}$ facteur majeur limitant la production de cette culture de mil en Éthiopie. Une expérience au champs a été conduite avec douze génotypes des grains noir de mil (Eleusine coracana subsp. Coracana), y compris des contrôles locaux et standard (Degu) à deux locations (Bako et Gute) en Éthiopie pendant trois ans (2014 - 2016). L'objectif de cette étude était d'identifier des génotypes stables et de rendement très élevé pour le rendement en grain de mil et d'autres caractéristiques agronomiques parmi les genotypes des grains noir de mil en Éthiopie. L'analyse de variance du methode avec effet principal additif et interaction multiplicative $(\mathrm{AIM})$ a révélé des différences très significatives $(\mathrm{P}<0,01)$ entre les locations, le génotype et l'analyse en composantes principales de l'interaction (IPCA-I), mais des variations significatives $(\mathrm{P}<0,05)$ pour $\mathrm{G} x$ E interactions. Cela indique que les génotypes se sont comportés différemment selon les locations et que les locations de test sont très variables. Seule la première IPCA-I a montré une signification élevée ( $\mathrm{P}<0,01)$ et a contribué pour $48,39 \%$ du total des interactions génotype par la location ( $\mathrm{G}$ x E). Génotypes BKFM0020, BKFM0006 et BKFM0010, qui avait un rendement en grain élevé, mais avec une valeur IPCA proche de zéro, a indiqué la grande adaptabilité / stabilité. De même, une analyse utilisant les méthodes d'Eberhart et Russell a révélé que ces génotypes se situaient dans la plage relativement acceptable des coefficients de régression (bi), se rapprochant de un $(0,742,0,8176$ et $1,0578)$ et de l'écart par rapport à la régression proche de zéro (s2di) $(0,0385,0,0661$ et -0,0248), respectivement. Cela impliquait que les génotypes de pipeline étaient stables, largement adaptables et ont eu le rendement très élevé que les autres génotypes. Les analyses de génotype et génotype par la location (bi-parcelle GGE) ont également révélé que ces génotypes candidats étaient stables et avaient une bonne rentabilité. En outre, ces génotypes ont montré une résistance à la maladie fongique qui constitue une menace pour la production de mil dans les zones d'étude. Par conséquent, ces génotypes ont été sélectionnés comme candidats potentiels pour une libération éventuelle dans l'ouest d'Oromia et des zones agro-écologiques similaires du pays.

Mots Clés: AMI, maladie fongique, Eleusine coracana

\section{INTRODUCTION}

Finger millet (Eleusine coracana (L.) Gaertn) is an annual cereal crop and an allotetraploid $(2 \mathrm{n}=4 \mathrm{x}=36)$ that includes two distinct subspecies: subsp. coracana (cultivated finger millet) and subsp. Africana (wild finger millet) (Hilu, 1994) is preferred as potentially a climate-resilient and nutritious crop, having antioxidant properties (Kumar et al., 2017). Finger millet grain is gluten-free, rich in calcium, fiber and iron; and with excellent malting qualities (Chandrashekar, 2010; Pradhan et al., 2010). Finger millet, commonly called "Dagussa" in Ethiopia, is an important staple food crop, widely grown in the country (CSA, 2016). Despite its importance, there are numerous production and productivity limiting factors, including blast disease caused by Magnaporthe grisea (anamorph Pyricularia grisea); absence of stable, high yielding and disease tolerant finger millet varieties, and limited attention given to research and development of the crop.

Genetic variability is a prerequisite for a breeding programme and provides opportunities to breeders to select high yielding genotypes, or to combine or transfer genes 
with desirable traits. Phenotypic expression and yield potential of a given genotype is based on its genetics, the environment and the GXE interactions (Yan, 2001; Yan and Hunt, 2001). Genotypes by environment ( $\mathrm{G} \quad \mathrm{x} \quad \mathrm{E})$ interactions are conceived to be among the key factors limiting response to selection and the efficiency of breeding programs. Environment change can affect the performance of a genotypes, and breeders should give due attention to the impact of GXE in genetic exploitation to efficient in selection.

Ghaderi et al. (1980) observed that analysis of variance procedure helps to estimate the magnitude of GXE interaction; but is unable to provide information on the contribution of each genotypes and environment to GXE interactions. On the other hand, analytical models like additive main effects and multiplicative interaction (AMMI) can treat both the additive main effect and multiplicative interaction components employing the analysis of variance (ANOVA) and Interaction Principal Components (IPCA) (Gauch and Zobel, 1996). Besides, AMMI and GG bi-plot analysis are considered to be effective graphical tools to estimate genotype by environment interaction patterns (Gauch and Zobel, 1996; Yuksel et al., 2002. Also, the regression model suggested by Eberhart and Russell (1966) allows for the computation of a complete analysis of variance with individual stability regression coefficient (bi) estimates deviation from regression line $\left(\mathrm{s}^{2} \mathrm{di}\right)$. Based on the model, a stable variety is one with a high mean yield, $\mathrm{bi}=1$ and $\mathrm{s}^{2} \mathrm{di}=$ 0 . The Eberhart and Russell (1996) model and AMMI stability analysis are preferred tools for identifying stable and high yielding and genotype(s) for varied or specific environments. Plant breeders need to identify adaptable and stable high yielding genotypes, with other desirable traits, under varying environmental conditions prior to release as a variety (Flores et al., 1998; Showemimo et al., 2000; Mustapha et al., 2001).

The objective of the present study was to develop adaptable, stable and high yielding, disease tolerant black seeded finger millet varieties for agro ecologies of the western Oromia and Ethiopia in general.

\section{MATERIALS AND METHODS}

Twelve black seeded finger millet (Eleusine coracana (L.) Gaertn) genotypes, including local and standard check (Table 1) were tested at Bako and Gute research stations in Ethiopia for three cropping seasons (2014-2016). Bako Agricultural Research Center (BARC) is located at $9^{\circ} 6^{\prime} \mathrm{N}$ latitude and $37^{\circ} 09^{\prime} \mathrm{E}$ longitude with altitude of 1650 m.a.s.l. Mean and maximum temperature of the last 5 years is 13.1 and $28.4^{\circ} \mathrm{C}$, respectively. Average 5 years relative humidity of the Bako station is $53.2 \%$ (BARC Agro-Metrology department) and the soil is deeply weathered and slightly acidic in reaction (Wakene, 2000).

Gute sub-station is also found at west and lies at $09^{\circ} 01.06^{\prime} \mathrm{N}$ and $036^{\circ} 38.196^{\prime} \mathrm{E}$ with altitude of $1915 \mathrm{~m} . \mathrm{l}$. The average rain fall of $1431 \mathrm{~mm}$ per annum and clay loom soil with slightly acidic property. The min and maximum temperature is 12.32 and $32{ }^{\circ} \mathrm{C}$, respectively. The two research stations have unimodal pattern of rain distribution, with the rainy period running from April to October.

Genotypes were planted in a randomised complete block design (RCBD), with three replications. Each plot comprised of five rows having $5 \mathrm{~m}$ length; the middle three rows were harvestable and the spacing between rows was $40 \mathrm{~cm}$. A seed rate of $15 \mathrm{~kg} \mathrm{ha}^{-1}$ and fertiliser rate of $110 \mathrm{~kg} \mathrm{ha}^{-1}$ DAP and $65 \mathrm{~kg} \mathrm{ha}^{-1}$ urea were used. Urea was applied in split form; half at planting and the rest half at 35 days after emergence.

Data analysis. Grain yield data were subjected to analysis of variance (ANOVA) using GenStat Discovery Edition $16^{\text {th }}$ software. Grain yield stability analysis was carried out using regression (Eberhart and Russell, 1966) and AMMI models in Agrobase software (Agrobase, 2000) and genotype and genotype 
TABLE 1. Genotypes and the test environments with their finger millet codes used in a study in Ethiopia

\begin{tabular}{llcccc}
\hline No. & Genotype & Genotype code & No. & Environment & Environment code \\
\hline 1 & Local check & $\mathrm{a}$ & 1 & Bako 2014 & A \\
2 & BKFM0020 & $\mathrm{b}$ & 2 & Bako2015 & B \\
3 & BKFM0023 & $\mathrm{c}$ & 3 & Bako2016 & $\mathrm{C}$ \\
4 & 215984 & $\mathrm{~d}$ & 4 & Gute 2014 & $\mathrm{D}$ \\
5 & BKFM0006 & $\mathrm{e}$ & 5 & Gute2015 & E \\
6 & BKFM0024 & $\mathrm{f}$ & 6 & Gute2016 & F \\
7 & BKFM0010 & $\mathrm{g}$ & & & \\
8 & 216045 & $\mathrm{~h}$ & & & \\
9 & BKFM0014 & $\mathrm{i}$ & & & \\
10 & BKFM0001 & $\mathrm{j}$ & & & \\
11 & 216035 & $\mathrm{k}$ & & & \\
12 & Degu (Stand Check) & $\mathrm{l}$ & & & \\
\hline
\end{tabular}

by environment (GGE) Biplot using Genstat15th edition software.

Additive main effect and multiplicative interaction (AMMI) model. The AMMI model equation was used:

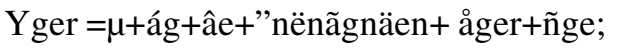

Where:

Yger is the observed yield of genotype $(\mathrm{g})$ in environment (e) for replication (r); Additive parameters: $\mu$ is the grand mean; ág is the deviation of genotype $\mathrm{g}$ from the grand mean, âe is the deviation of the environment $e$; Multiplicative parameters: ën is the singular value for IPCA, ãgn is the genotype eigenvector for axis $n$, and äen is the environment eigenvector; åger is error term and ñge is PCA residual.

\section{Eberhart and Russell Regression Model.}

The Eberhat and Russel model was used and is represented by:

$Y i j=\mu i+b i I j+S 2 d i j ;$

Where:
Yij is the mean performance of the $i^{\text {th }}$ variety $(\mathrm{I}=1,2,3 \ldots, \mathrm{n})$ in the $\mathrm{i}^{\text {th }}$ environment; $\mu \mathrm{i}$ is the mean of the ith variety over all the environments; bi is the regression coefficient which measures the response of $i^{\text {th }}$ variety to varying environments; $S^{2}$ dij is the deviation from regression of $i^{\text {th }}$ variety in the $i^{\text {th }}$ environment; and Ij is the environmental index of the $\mathrm{i}^{\text {th }}$ environment.

Genotype and genotype by environment interaction (GGE) biplot. To determine genotype by environment interaction and stability analysis, different methods were used. The genotypes and genotype by environment (GGE) biplot analysis is the most common currently utilised (Yan and Tinker 2005; Yan et al., 2007). GGE biplot analysis was carried out using the method proposed by Yan (2001) for multi environment data.

\section{RESULTS AND DISCUSSION}

Analysis of variance. There were significant differences between black seeded finger millet genotypes for the grain yield in all environments, except Gute 2015 and 2016 (Table 2). This indicates the presence of genetic variability among the genotypes in the 
TABLE 2. Grain yield $\left(\mathrm{t} \mathrm{ha}^{-1}\right)$ for the tested genotypes over location and across years in Ethiopia

\begin{tabular}{|c|c|c|c|c|c|c|c|c|}
\hline \multirow[t]{3}{*}{ Genotype } & \multicolumn{6}{|c|}{ Genotypes performance across environments } & \multirow[t]{3}{*}{ Mean } & \multirow[t]{3}{*}{ BSS } \\
\hline & \multicolumn{3}{|c|}{ Bako } & \multicolumn{3}{|c|}{ Gute } & & \\
\hline & 2014 & 2015 & 2016 & 2014 & 2015 & 2016 & & \\
\hline 215984 & 1.136 & 3.205 & 1.821 & 1.841 & 1.406 & 2.146 & 1.93 & 2 \\
\hline 216035 & 1.301 & 2.531 & 2.177 & 2.557 & 1.657 & 2.535 & 2.13 & 1 \\
\hline 216045 & 1.042 & 3.064 & 1.412 & 2.304 & 1.374 & 2.67 & 1.98 & 1 \\
\hline BKFM0001 & 1.469 & 3.342 & 2.184 & 3.059 & 1.204 & 2.427 & 2.28 & 1 \\
\hline BKFM0006 & 1.814 & 3.263 & 2.562 & 2.776 & 2.015 & 2.886 & 2.56 & 1 \\
\hline BKFM0010 & 1.196 & 3.694 & 2.247 & 3.228 & 1.376 & 2.508 & 2.38 & 1 \\
\hline BKFM0014 & 1.578 & 2.979 & 1.748 & 2.776 & 1.338 & 1.813 & 2.04 & 2 \\
\hline BKFM0020 & 2.56 & 3.849 & 2.721 & 2.889 & 2.146 & 2.41 & 2.78 & 1 \\
\hline BKFM0023 & 1.617 & 3.367 & 1.984 & 3.327 & 1.788 & 1.9 & 2.33 & 2 \\
\hline BKFM0024 & 0.938 & 2.92 & 1.669 & 3.189 & 1.458 & 2.44 & 2.10 & 2 \\
\hline Degu & 1.59 & 2.636 & 1.926 & 1.526 & 1.343 & 1.628 & 1.78 & 2 \\
\hline Local & 0.972 & 2.68 & 2.264 & 1.723 & 1.313 & 2.544 & 1.92 & 2 \\
\hline Mean & 1.435 & 3.127 & 2.06 & 2.6 & 1.535 & 2.325 & 2.18 & \\
\hline LSD & 0.579 & 0.794 & 0.712 & 0.977 & 0.7692 & 0.945 & 0.796 & \\
\hline $\mathrm{CV}$ & 23.8 & 15 & 20.3 & 22.2 & 29.2 & 23.9 & & \\
\hline F-value & $* *$ & $*$ & $*$ & $* *$ & $\mathrm{~ns}$ & $\mathrm{~ns}$ & & \\
\hline
\end{tabular}

BSS = Blast Severity Score (1-5), CV = coefficient of variation, LSD = Least Significant Difference

wide-range of environments. The mean grain yield of the twelve tested genotypes ranged from $1.775 \mathrm{t} \mathrm{ha}^{-1}$ (Degu) to $2.763 \mathrm{t} \mathrm{ha}^{-1}$ (BKFM0020), with a grand mean of $2.18 \mathrm{t}$ ha $^{-1}$ (Table 2).

\section{Stability analysis}

Additive Main Effects and Multiplicative Interaction (AMMI) Model. The combined analysis of variance revealed highly significant $(\mathrm{P}<0.01)$ variations among environments, genotypes, and Principal Component Analysis IPCA-1 and IPCA 2; and significant difference $(\mathrm{P}<0.05)$ for genotype $\mathrm{x}$ environment interactions; but non-significant differences for the remaining (IPCA) interaction (Table 3). This showed that the genotypes responded differently over environments, or genotypes responses were affected by environment, and thus the test environments were highly variable. The mean grain yield across the six environments ranged from $1.435 \mathrm{tha}^{-1}$ at Bako in 2014 to $3.127 \mathrm{t} \mathrm{ha}^{-1}$ at Bako in 2015 (Table 2 ). This implies genotypes and locations differences including seasons'. Environmental conditions during different seasons significantly influenced grain yield, indicating that environments and genotypes were significant variable. Similar results were reported by Kebede et al. (2016) and Kebede et al. (2018), in brown seeded finger millets; Ezeaku et al. (2014) in pearl millet and Dagnachew et al. (2014) in Triticale.

The IPCA scores of genotypes in AMMI analysis are an indication of the adaptability over environments and association between genotypes and environments (Gauch and Zobel, 1996; Alberts, 2004). The IPCA scores of genotypes in the present study (Table 4) 
TABLE 3. Analysis of variance for additive main effects and Multiple Interaction (AMMI) for yield stability of black seeded finger millet genotypes in Ethiopia

\begin{tabular}{|c|c|c|c|c|c|}
\hline Source & df & SS & MS & $\% \mathrm{GXE}$ & $\begin{array}{c}\% \text { cumulative } \\
\text { interaction } \\
\text { Explained }\end{array}$ \\
\hline Environments & 5 & 75.606 & $15.121 * *$ & & \\
\hline Genotypes & 11 & 16.71 & $1.519 * *$ & & \\
\hline Genotype x Envt. Interactions & 55 & 23.544 & $0.428^{*}$ & & \\
\hline IPCA I & 15 & 11.394 & $0.760 * *$ & 48.39 & 48.39 \\
\hline IPCA II & 13 & 6.74 & $0.518 *$ & 28.63 & 77.02 \\
\hline IPCA III & 11 & 3.276 & $0.298 \mathrm{~ns}$ & 13.91 & 90.93 \\
\hline Residuals & 132 & 35.702 & 0.27 & & \\
\hline
\end{tabular}

Grand mean $=2.18 ; \mathrm{R} 2=0.7719 ;$ Coefficient of variation $(\mathrm{CV}, \%)=23.98 \% ; *$, ** $=$ Significant at $\mathrm{P}<0.05$ and $\mathrm{P}<0.01$ levels, respectively

TABLE 4. Grain yield (GY) $\left(\mathrm{t} \mathrm{ha}^{-1}\right)$ and IPCA1 scores of black seeded finger millet genotypes assessed for stability in Ethiopia

\begin{tabular}{llcc}
\hline Description of genotypes & Genotype name & IPCA1 score & Mean GY $\left(\mathrm{t} \mathrm{ha}^{-1}\right)$ \\
\hline $\mathrm{a}$ & Local & -0.4924 & 1.92 \\
$\mathrm{~b}$ & BKFM0020 & -0.3531 & 2.78 \\
$\mathrm{c}$ & BKFM0023 & 0.3325 & 2.34 \\
$\mathrm{~d}$ & 215984 & -0.2789 & 1.93 \\
$\mathrm{e}$ & BKFM0006 & -0.2144 & 2.56 \\
$\mathrm{f}$ & BKFM0024 & 0.5276 & 2.10 \\
$\mathrm{~g}$ & BKFM0010 & 0.06458 & 2.38 \\
$\mathrm{~h}$ & 216045 & 0.3091 & 1.91 \\
$\mathrm{i}$ & BKFM0014 & 0.1353 & 2.05 \\
$\mathrm{j}$ & BKFM0001 & 0.2232 & 2.28 \\
$\mathrm{k}$ & 216035 & -0.1529 & 2.13 \\
$\mathrm{l}$ & Degu & -0.6818 & 1.78 \\
& & & \\
Environments & & & \\
$\mathrm{A}$ & Bako2014 & -0.4415 & 1.44 \\
$\mathrm{~B}$ & Bako2015 & 0.2633 & 3.13 \\
$\mathrm{C}$ & Bako2016 & -0.7193 & 1.97 \\
$\mathrm{D}$ & Gute2014 & 1.0516 & 2.61 \\
E & Gute2015 & -0.2344 & 1.55 \\
$\mathrm{~F}$ & Gute2016 & 0.0804 & 2.31 \\
\hline
\end{tabular}

$\mathrm{A}=\mathrm{BKFM0010,} \mathrm{b}=\mathrm{BKFM0010}, \mathrm{c}=216045, \mathrm{~d}=\mathrm{BKFM0014}, \mathrm{e}=\mathrm{BKFM0001,} \mathrm{f}=216035, \mathrm{~g}=$ Degu; $\mathrm{A}=$ Bako 2014, $\mathrm{B}=$ Bako2015, $\mathrm{C}=$ Bako2016, $\mathrm{E}=$ Gute 2014, $\mathrm{F}=$ Gute2015, $\mathrm{G}=$ Gute2016 
showed that a significant proportion of main GxE interaction (48.39\%) was explained by IPCA-I; followed by 28.63 and $13.91 \%$ for IPCA-II and IPCA-III, respectively. The first and second IPCA were significant, but the remaining IPCA axes were not significant (Table 3).

In this study, we chose the first and second IPCAs to describe genotype by environment interaction and placement on the bi-plots. Accordingly, the AMMI analysis result revealed that BKFM0020, BKFM006 and BKFM0010 attained IPCA values of 0.3531, 0.06458 and -0.2144 ,respectively, relatively close to zero, and gave relatively high yield. Hence, they are better stable and widely adaptable genotypes across location, than the standard check and other tested genotypes (Table 4). BKFM0014, 216035, BKFM001 and 215984 scored IPCA values close to zero ($0.1529,0.2232$, and -0.2789 ), but gave lower mean grain yield than the above genotypes (BKFM0014, 216035, BKFM001) selected as relatively stable and high yielder. Degu and Acc BKFM0024 scored IPCA values deviating from zero (-0.6818 and 0.5276) (Table 3) and lower grain yield, indicating that these genotypes are unstable and are environment sensitive. Several researchers reported results that are in agreement with the present study, that genotypes with low grain yield and IPCA value deviated zero are not stable and are highly environmental sensitive, (Yuksel et al., 2002; Asnake Worku et al., 2013; Ezeaku et al., 2014).

According to AMMI biplot, environments showed high variations in both main effects and interactions (IPCA 1). Environments Gute 2014 and 2016, and Bako 2015 were plotted in the first quadrant for their high mean grain yield, and had positive IPCA 1 scores, which interacted positively with genotypes that had positive IPCA 1 scores; and negatively with genotypes having negative IPCA 1 scores. Bako 2015 gave the higher environmental mean yields $\left(3.13 \mathrm{t} \mathrm{ha}^{-1}\right)$ and was the best preforming environment. Similarly, BKFM0020 and
BKFM0010 gave the higher grain yield (3.849 and $3.694 \mathrm{t} \mathrm{ha}^{-1}$, respectively) at Bako location during the 2015 cropping season, than they did at other locations and years. On the other hand, the least mean grain yield was harvested from Bako during 2014 (Table 4). Bako 2015 showed high interactions, while Gute 2016 was in the $1^{\text {st }}$ quadrant, but with relatively low interaction (Fig. 1). Similarly, according to Misra et al. (2009), genotypes scattered close to the origin, indicated minimal interactions of genotypes by environments.

Therefore, genotypes BKFM0020, BKFM0006 and BKFM0010 are candidates for variety verification as revealed by AMMI model analysis result (Table 4) and based on the actual field performance observation. Further analysis using Eberhart and Russell regression model confirmed the result obtained by AMMI model.

AMMI bi-plot indicated that genotypes BKFM0020, BKFM0006 and BKFM0010 are plotted closer to the horizontal IPCA stability line and far from vertical IPCA mean value. This showed that these genotypes were a stable and high yielding (Fig. 1).

\section{Regression analysis based on Eberhart and} Russell Model. Ebrehart and Russell (1966) model hypothesizes that genotypes with high yield and regression coefficient (bi) equal to unity (1), and deviation from regression $\left(\mathrm{s}^{2} \mathrm{di}\right)$ approach to zero, would be selected as stable genotypes and proposed as potential candidates for possible release. An ideal genotype has the highest grain yield, a regression coefficient (bi) value of approximately one, and a mean square deviation from regression $\left(\mathrm{s}^{2} \mathrm{di}\right)$ value close to zero. Accordingly, pipeline genotypes, BKFM0020, BKFM0006 and BKFM0010, were the most promising candidates and gave grain yield of 2.78, 2.56 and $2.38 \mathrm{t} \mathrm{ha}^{-1}$, respectively. The regression coefficients (bi) for those genotypes were approaching one $(0.742,0.8176$ and 1.0578$)$ and acceptable deviation from regression $\left(\mathrm{s}^{2} \mathrm{di}\right)(0.0385$, 0.0661 and -0.0248 ), respectively; implying 


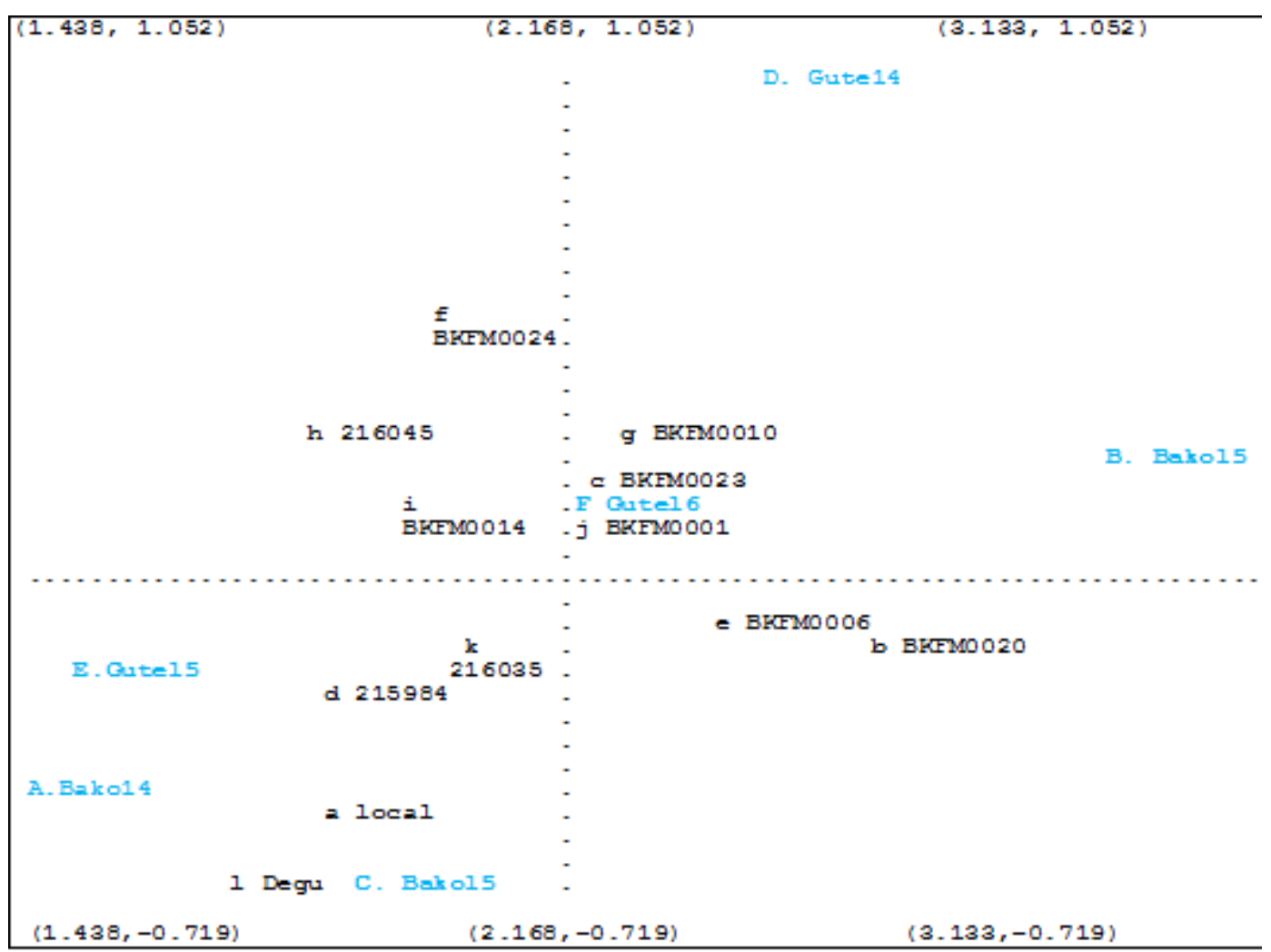

Figure 1. AMMI Biplot showing black seeded finger millet genotypes grain yield stability and preferential adaptation over environment in Ethiopia. $A=B K F M 0010, b=B K F M 0010, c=216045, d=$ BKFM0014, e = BKFM0001, $\mathrm{f}=216035, \mathrm{~g}=$ Degu; $\mathrm{A}=$ Bako 2014, $\mathrm{B}=$ Bako2015, $\mathrm{C}=\mathrm{Bako2016}, \mathrm{E}=$ Gute 2014, $\mathrm{F}=$ Gute2015, $\mathrm{G}=$ Gute2016

TABLE 5. Analysis of variance for grain yield for black seeded finger millet genotypes using the Eberhart and Russell Regression Model

\begin{tabular}{lrrr}
\hline Source & df & \multicolumn{1}{c}{ SS } & Mean square (MS) \\
\hline Total & 215 & 38.620 & \\
Varieties & 11 & 5.570 & $0.506^{* *}$ \\
Env.+ in Var.x Env. & 60 & 33.050 & 0.551 \\
Env. in linear & 1 & 25.202 & \\
Var. x Env. (linear) & 11 & 2.029 & $0.184 \mathrm{Ns}$ \\
Pooled deviation & 48 & 5.819 & 0.121 \\
\hline
\end{tabular}

Grand mean $=2.18 ; \mathrm{R} 2=0.8239 ;$ Coefficient of variation $=24.51 \%, * *=*, * *=$ Significant at $\mathrm{P}<0.05$ and $\mathrm{P}<0.01$ levels, respectively 
that they are stable, widely adaptable and higher yielders than the other genotypes (Table 6). Kebede et al. (2016) reported similar result of stability and wide adaptability of finger millet genotypes tested over locations. Supportive results were also reported by Farshadfar (2008).

The regression coefficients were significantly different from unity (Table 6); and square deviation from regression $\left(\mathrm{s}^{2} \mathrm{di}\right)$ value deviate from zero (Table 6) for 216045; and regression coefficients highly deviated from unity for Degu (Table 6). This indicates that the above genotypes are less stable and are not adaptable over the environments. Genotypes, 215984, BKFM0023 and BKFM0014 showed better stability and, were widely adaptable over the environment; but were inferior in grain yield. The result obtained using Eberhart and Russell (1966) model is in agreement with that of the AMMI model. Supportive findings were reported by Dogan et al. (2011) that significant differences between genotypes for grain yield of eight triticale lines evaluated across six environments.

Stability analysis. The biplot for grain yield explained $76.55 \%$ of the total variation $(50.02$ and $26.53 \%$ by PC1 and PC2, respectively) (Fig. 2). The biplot showed that genotype BKFM0020 was in the first concentric circle, closer to IPCA stability horizontal line; followed by BKFM0006 and BKFM0010 and away from the mean vertical line. This was an indication of the genotypes that were the most stable and high yielders among the tested genotypes. Whereas Acc 218045 and Acc 216035 were the best stable genotypes, but showed an inferior mean grain yield, even far below the average (1.91 and $\left.2.13 \mathrm{t}^{-1}\right)$. Genotypes BKFM0023 gave high grain yields, but far/ deviate from the mean horizontal line, which indicates that the genotype was not stable (Fig. 2 ). This result is in agreement with the above two models results. Earlier researchers also identified stable finger millet genotypes for the brown seeded groups (Asfaw Adugna et al.,

TABLE 6. Regression coefficient (bi) and squared deviation from linearity of regression (s2di) by the test black seeded finger millet genotypes using Eberhart and Russell model

\begin{tabular}{lccc}
\hline Genotypes & $\begin{array}{c}\text { Regression } \\
\text { coefficient (bi) }\end{array}$ & $\begin{array}{c}\text { Squared deviations } \\
\text { from regression (S2di) }\end{array}$ & $\begin{array}{c}\text { Grain yield } \\
\left(\mathrm{t} \mathrm{ha}^{-1}\right)\end{array}$ \\
\hline Local & 0.8531 & 0.1408 & 1.92 \\
BKFM0020 & 0.7416 & 0.0385 & 2.78 \\
BKFM0023 & 1.1115 & 0.0702 & 2.34 \\
215984 & 1.0165 & 0.0095 & 1.93 \\
BKFM0006 & 0.8176 & -0.0661 & 2.56 \\
BKFM0024 & 1.2493 & 0.0580 & 2.10 \\
BKFM0010 & 1.0578 & -0.0284 & 2.38 \\
216045 & 1.1817 & 0.1351 & 1.91 \\
BKFM0014 & 0.9784 & -0.0117 & 2.05 \\
BKFM0001 & 1.2590 & -0.0387 & 2.28 \\
216035 & 0.7171 & -0.0184 & 2.13 \\
Degu & 0.4956 & 0.0358 & 1.78 \\
Local & 0.8531 & 0.1408 & 1.92 \\
BKFM0020 & 0.7416 & 0.0385 & 2.78 \\
BKFM0023 & 1.1115 & 0.0702 & 2.34 \\
\hline
\end{tabular}

Standard error of beta $=0.2403 ; \mathrm{t}=$ Tons; $\mathrm{ha}=$ Hectare 
Comparison biplot (Total - 76.55\%)

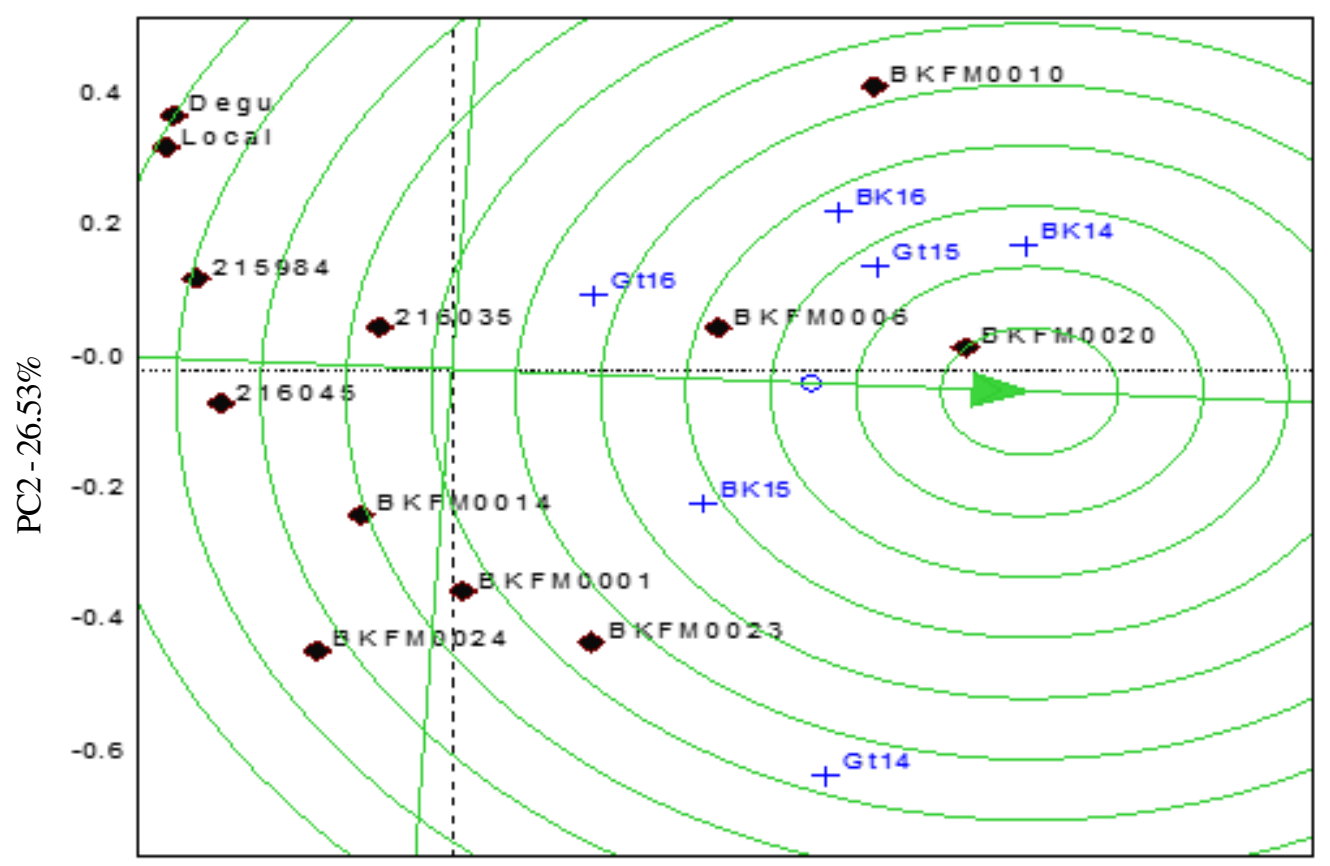

PC1 $-50.02 \%$

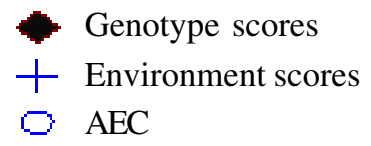

Figure 2. GGE Biplot analysis showing grain yield stability of black seeded finger millet genotypes and environments in Ethiopia.

2011; Kebede et al., 2016; Kebede et al., 2018).

The GGE biplot (Fig. 3) indicates the best performing genotype(s) for specific environment and the group of environments. The rays of the biplot divided the plot into six sections. The environments appeared in three of them, revealing three mega-environments. According to Yan et al. (2007), when different environments fall into different sectors, it shows that they have different high yielding cultivars for those sectors and also the presence of a cross over interaction.

The genotype at the vertex of the polygon performs best in the environment falling within the sectors (Yan, 2002; Yan and Tinker, 2006).
Accordingly, BKFM0020 performs best at Bako 2014; whereas BKFM0010 performs best at Bako 2016, Bako 2014, Gute 2015 and Gute 2016 (Fig. 3). Similar results were reported by Yan and Tnker (2005) that, biplot displays the yield-trait relations in individual environments and addresses whether and how the genotype $\times$ environment interactions (GXE) for yield can be explored by indirect selection for the traits. Presence of wide obtuse angles between environment vectors (Fig. 4) indicates strong negative correlations among the test environments, suggesting existence of strong crossover GE across some locations for grain yield (Yan and Tinker, 2006). This indicates that genotypes 
Scatter plot (Total - 76.55\%)

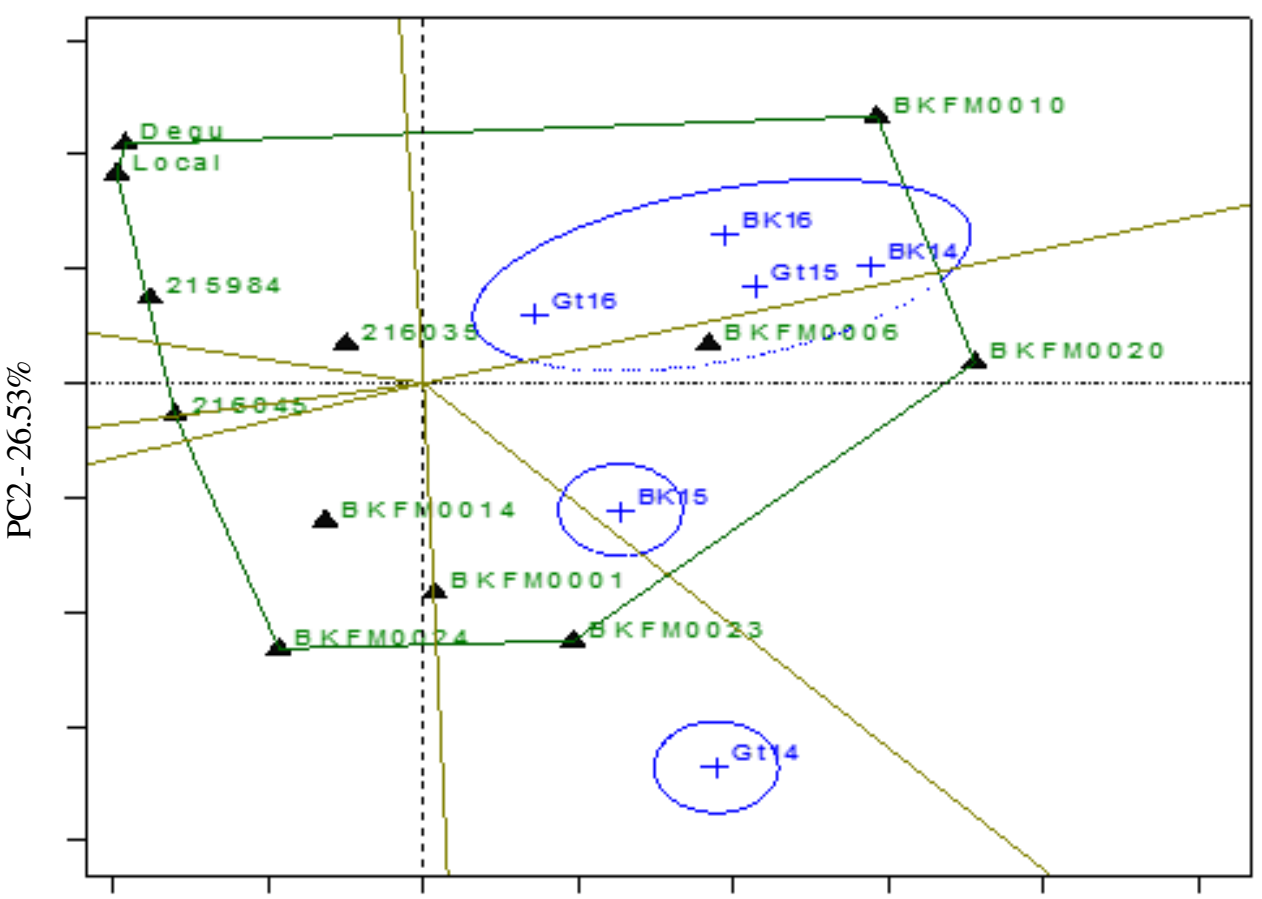

PC1 $-50.02 \%$

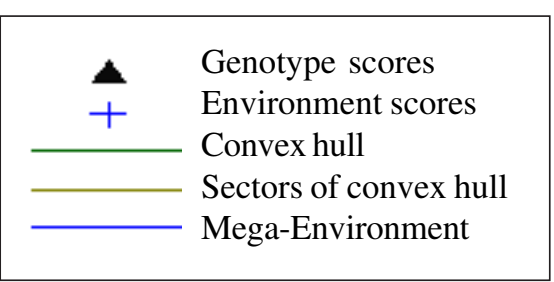

Figure 3. Polygon view of the GGE biplot based on grain yield for the environments.

performing better in one environment would perform poorly in another environment. At the same time, closer relationships among other locations are indicative of non-existence of crossover GxE, suggesting that ranking of genotype does not change from location to location.

In general, AMMI, GGE biplot and Eberhart and Russell model analysis results confirmed that BKFM0020, BKFM006 and BKFM0010 were stable and high yielding genotypes and were therefore, selected and proposed to Variety Verification Trial (VVT) for possible release under wider environmental conditions of the test locations and similar agro-ecologies of the country.

\section{CONCLUSION}

Based on the stability test model result, black seeded finger millet genotypes such as BKFM0020, BKFM0006 and BKFM0010 give high grain yield, better adaptability and more stable performance than all tested genotypes. The genotypes are also relatively tolerant to blast disease.

A GxE interaction of $48.39 \%$ is explained by IPCA-I; followed by 28.63 and $13.91 \%$ for 


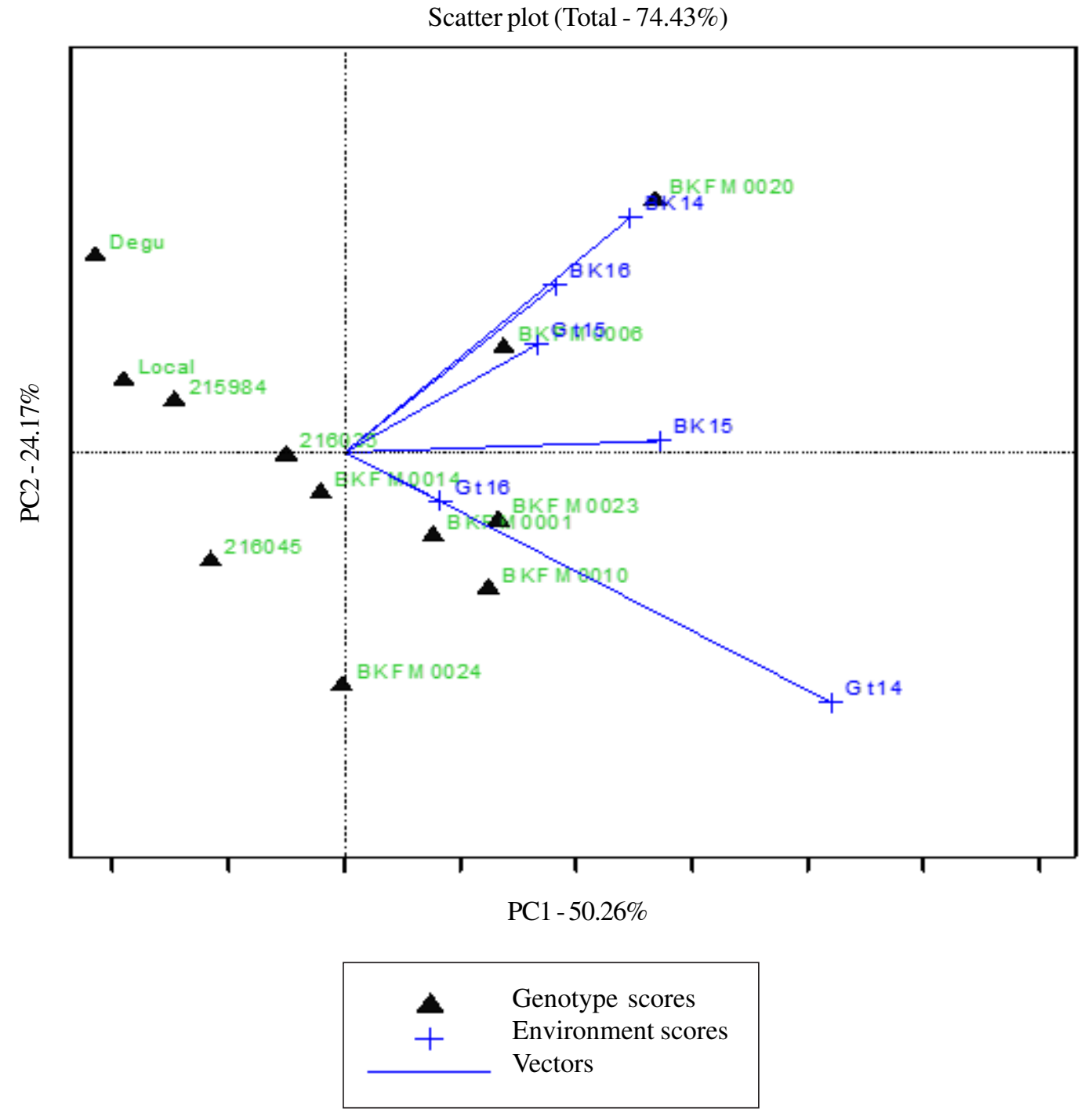

Figure 4. GGE biplot based on grain yield for the 12 genotypes showing the relationship among environments

IPCA-II and IPCA-III, respectively. The first and second IPCA are significant, but the remaining IPCA axes are not significant. AMMI analysis result reveals that BKFM0020, BKFM006 and BKFM0010 attains IPCA values relatively close to zero $(0.3531,-0.6458$ and 0.2144 ) and give better yield, and hence are better stable and widely adaptable genotypes across location with higher yield. BKFM0014, 216035, BKFM001 and 215984, with IPCA value close to zero $(0.1353,-0.1529,0.2232$ and -0.2789 , respectively) are relatively stable, but give lower grain yield. Degu and BKFM0024 give lower mean grain yield and scored IPCA value deviating from zero (0.6818 and 0.5276 ), indicated, these genotypes are not stable.

According to Eberhart and Russell regression model, genotypes BKFM0020, BKFM006 and BKFM0010 are stable and 
widely adapted. Based on the regression, AMMI and GGE Biplot analyses, therefore, BKFM0020, BKFM006 and BKFM0010 are the most stable and high yielding genotypes and as a result, they are proposed for variety verification for Bako, Gute and similar agroecologies of the western Oromia, Ethiopia. Thus, they are recommended for possible release for wider adaptability around Bako and Gute including areas with similar agro-ecology in the country.

\section{ACKNOWLEDGMENT}

We acknowledge Oromia Agricultural Research Institute for funding the research. The authors are also grateful to Bako Agricultural Research Center and all staff members of the Cereal Technology Generation Team for their devoted experimental field management and data collection, and the whole implementation of the experiment.

\section{REFERENCES}

Alberts, M.J.A. 2004. A comparison of statistical methods to describe genotype $\mathrm{x}$ environment interaction and yield stability in multi-location maize trials. Ph.D. Thesis, Department of Plant Sciences (Plant Breeding), Faculty of Natural and Agricultural Sciences of the University of the Free State, Bloemfontein, South Africa. pp. 7-35.

Asfaw Adugna1, Tesfaye Tesso, Erenso Degu, Taye Tadesse, Feyera Merga, Wasihun Legesse, Alemu Tirfessa, Haileselassie Kidane, Andualem Wole, Chemeda Daba 2011. Genotype-by-environment interaction and yield stability analysis in finger millet (Elucine coracana L. Gaertn) in Ethiopia. American Journal of Plant Sciences 2:408-415.

Asnake Worku, Mwambi, H., Temesgen Zewotir and Gairma Taye. 2013. Additive main effects and multiplicative interactions model (AMMI) and genotype main effect and genotype by environment interaction (GGE) biplot analysis of multienvironmental wheat variety trials. African Journal of Agricultural Research 8(12):1033- 1040

Chandrashekar, A. 2010. Finger millet: Eleusine coracana. Advances in Food and Nutrition Research 59:215-262. 10.1016/ S1043-4526(10)59006-5.

Central Statistical Agency (CSA). 2016. Agricultural survey report on area and production of major crops (1).

Dagnachew Lule, Kassahun Tesfaye, and Girma Mengistu. 2014. Genotype by environment interaction and grain yield stability analysis for advanced triticale ( $x$. triticosecale wittmack) genotypes in western Oromia. Ethiopian Journal of Science 37(1):63-68.

Dogan, R., Kacar, O., Goksu, E. and Azkan, N. 2011. Evaluation of triticale genotypes in terms of yield stability for the southern Marmara Region. Notulae Botanicae Horti Agrobotanici Cluj-Napoca 39(2):249-253.

Eberhart, S.A. and Russell, W.A. 1966. Stability parameters for comparing varieties. Crop Science 6:36-40.

Ezeaku, I.E., Angarowai I.I., Aladele S.E. and Mohammed S.G. 2014. Genotype by Environment interactions and phenotypic stability analysis for yield and yield components in parental lines of pearl millet (pennisetum glaucum [ L ]R.Br). African Journal of Agricultural Research 9(37): 2827-2833

Farshadfar, E. 2008. Incorporation of AMMI stability value and grain yield in a single non parametric index (genotype selection index) in bread wheat. Pakistan Journal of Biological Sciences 11:1791-1796.

Flores, F., Moreno, M.T. and Cubero, J.I. 1998. A comparison of univariate and multivariate methods to analyze GXE interaction. Field Crops Res. 56:271-286.

Gauch, H.G. and Zobel, R.W. 1996. AMMI analysis of yield trials. pp. 85-122. In: Genotype by environment interaction. 
Kang, M. and Gauch, H. (Eds.). Boca Raton. CRC Press, New York.

Ghaderi, A., Cress, C.E. and Everson, E.H 1980. Classification of environments and genotypes in wheat. American Journal of Crop Science 20(6):707-710

Hilu, K.W.1994. Validation of the combination Eleusine coracana subspecies Africana Phytologia 76(5):410-11

Kebede, D., Dagnachew, L., Girma, M., Kassa, M.., Chemeda, B., Girma, Ch. and Gudeta, B. 2018. Genotype by environment interaction and grain yield stability analysis for finger millet (Eleusine coracana (L.) Gaertn) genotypes from Western Oromia. Ethiopian Journal of Crop Science 6(1):119-133.

Kebede, D., Dagnachew, L., Girma, M., Kassa, M., Geleta, G., Chemeda, B., Hailu, F., Girma Ch. and Gudeta, B. 2016. Registration of 'Gudatu' finger millet (Eleusine coracana sub spp. coracana) Variety. East African Journal of Sciences 10 (1):71-72,

Kumar, A., Metwal, M., Kaur, S., Gupta, A.K., Puranik, S., Singh, S., Singh, M., Gupta, S., Babu, B.K. and Sood, S. 2017. Nutraceutical value of finger millet [Eleusine coracana (L.) Gaertn.], and their improvement using Omics approaches. Frontiers in Plant Science BMC Genomics 18:465.

Mustapha, A.A., Showemimo, F.A. and Aminu-kano, A. 2001. Yield stability analysis of promising triticale cultivars in Nigeria. Journal of Arid Agriculture 11:14. 20.

Pradhan, A., Nag, S. and Patil, S. 2010. Dietary management of finger millet (Eleusine coracana L. Gaerth) controls diabetes. Current Science 98(6):763-5
Misra, R.C., Das. S. and Patnaik, M.C. 2009. AMMI model analysis of stability and adaptability of late duration finger millet (Eleusine coracana) genotypes. World Applied. Science Journal 6(12):1650-1654. Showemimo, F.A., Echekwu, C.A. and Yeye, M.Y. 2000. Genotype $x$ environment interaction in Sorghum trials and their implication for future variety evaluation in Sorghum growing areas of northern Nigeria. The Plant Scientist 1:24-31.

Yan, W. and Tinker, N.A. 2006. Biplot analysis of multi-environment trial data: Principles and applications. Canadian Journal of Plant Science 86:623-645

Yan,W. and Tinker, N.A. 2005. An integrated biplot analysis system for displaying, interpreting, and exploring genotype by environment interaction. Crop Science 45: 1004-1016.

Yan, W. and Hunt, L.A. 2001. Interpretation of genotype $\mathrm{x}$ environment interaction for winter wheat yield in Ontario Crop Science 41: 19-25

Yan, W., Kang, B.M. Woods, S. and Cornelius, P.L. 2007. GGE biplot vs AMMI analysis of genotype by environment data. Crop Science 47:643-655.

Yan, W. 2002. Singular value partitioning for biplot analysis of multi-environment trial data. Agronomy Journal 4:990-996.

Yan,W. 2001. GGE Biplot-A Windows application for graphical analysis of multienvironment trial data and other types of two-way data. Agronomy Journal 93:11111118.

Yuksel Kaya, Palta, C. and Taner, S. 2002. Additive main effects and multiplicative interactions analysis of yield performances in bread wheat genotypes across environments. Turk Journal of Agriculture and Forestry 26:275-279. 